\title{
Dietary metal and macro-nutrient intakes of juvenile lemon sharks determined from the nutritional composition of prey items
}

\author{
Harri Pettitt-Wade ${ }^{1}$, Steven P. Newman ${ }^{1,2,5}$, Kristene T. Parsons ${ }^{3}$, \\ Samuel H. Gruber ${ }^{2,4}$, Richard D. Handy ${ }^{1, *}$ \\ ${ }^{1}$ School of Biomedical and Biological Sciences, University of Plymouth, Plymouth, Devon PL4 8AA, UK \\ ${ }^{2}$ Bimini Biological Field Station, Bimini, Bahamas \\ ${ }^{3}$ Department of Fisheries Science, Virginia Institute of Marine Science, College of William \& Mary, Gloucester Point, \\ Virginia 23072, USA \\ ${ }^{4}$ Rosential School for Marine and Atmospheric Science, University of Miami, Miami 33149-1098, Florida, USA \\ ${ }^{5}$ Present address: School of Marine Science and Technology, Newcastle University, Newcastle Upon Tyne, \\ Tyne and Wear NE1 7RU, UK
}

\begin{abstract}
The trace element requirements of sharks are poorly understood and the dietary intake of metals from prey items in wild sharks has not been measured. In this study whole prey of nursery bound juvenile lemon sharks Negaprion brevirostris, from Bimini, Bahamas were analysed for carcass total protein, lipids, carbohydrates, ash content, energy, and elemental composition. Metal analysis included 415 prey items from 18 species (fish: Atherinidae, Belonidae, Gerreidae, Haemulidae, Lutjanidae, Scaridae, Sphyraenidae; decapod crustaceans: Penaeidae, Portunidae). There were some seasonal and location effects (North Sound versus South Bimini shark nurseries), but overall prey metal concentrations were broadly similar to reports for temperate species. Yellow fin mojarra Gerres cinereus dominate the shark diet, in which electrolytes were similar (Na 10, K 10, Ca 65, and $\mathrm{Mg} 2 \mathrm{mg} \mathrm{g}^{-1}$ dry weight) but trace metals were higher (Cu 2.4, Zn 96, Fe 63, Mn $0.7 \mu g g^{-1}$ dry weight) than in other prey fish species at Bimini. Swimming crabs (Portunidae) were an important source of dietary $\mathrm{Ca}, \mathrm{Mg}, \mathrm{Cu}$ and $\mathrm{Mn}$ for lemon sharks. The calculated daily dietary metal intakes $\left(\mathrm{mg} \mathrm{d}^{-1}\right)$ for $\mathrm{Cu}(0.17), \mathrm{Fe}(1.2)$ and $\mathrm{Mn}(0.01)$ of lemon sharks are below previously estimated requirements of other fish. Dietary salt intake ( $272 \mathrm{mg} \mathrm{Na} \mathrm{d}{ }^{-1}, 1 \%$ dietary salt) is similar to other fishes, but the Ca and Zn intakes are higher. Yellow fin mojarra contained $65 \%$ protein, $4 \%$ lipid, $23 \%$ ash. The average juvenile lemon shark $(1.85 \mathrm{~kg}, 24.84 \mathrm{~g}$ daily ration) ate a very lean high protein diet $(61.9 \%$ protein, $4.6 \%$ lipid, $24.9 \%$ ash, $8.6 \%$ carbohydrate), with a calculated energy intake of $397 \mathrm{~kJ} \mathrm{~d}^{-1}$. Overall, the data suggests the gross macronutrient composition of the shark diet is adequate, but some of the trace metals may be limiting in the diet of wild juvenile lemon sharks at Bimini.
\end{abstract}

KEY WORDS: Dietary metal · Trace element $\cdot$ Electrolyte $\cdot$ Energy intake $\cdot$ Proximate composition Nutrition $\cdot$ Negaprion brevirostris $\cdot$ Bimini

- Resale or republication not permitted without written consent of the publisher

\section{INTRODUCTION}

The Florida Fish and Wildlife Commission recently implemented a total ban on the harvesting of the lemon shark Negaprion brevirostris, as an urgent measure to conserve the species. Lemon sharks are a threatened species. Classification as 'Near Threatened' on the International Union for Conservation of Nature (IUCN) Red List of Threatened Species is based on limited data collected some years ago, leading to an underesti- 
mation of their survivability rank on the list (Sundström 2005). Adequate food intake is a critical factor in the survival of any species. For sharks, research has mainly focused on measuring the energy content and the gross nutritional profile (protein, fat, carbohydrate) of teleost prey species so that the energy requirements of the sharks can be calculated (Wetherbee et al. 1990, Lawson et al. 1998, Eder \& Lewis 2005). Such information is used to aid understanding of bioenergetics, survival strategies and fish husbandry; as well as to inform conservation measures for the protection of top predators. Yet it is well known in fish nutrition that the energy, protein, fat or carbohydrate content of the food are not the only factors that may limit the growth or health of fishes. Other ingredients in the food such as vitamins and minerals can also have significant effects on fish health (Halver 1989). There has been extensive research on the trace metal requirements of teleost fish, especially those used in aquaculture, and many teleosts need a few milligrams per day of each trace element to remain healthy (Watanabe et al. 1997, Bury et al. 2003, Handy et al. 2005). However the dietary metal requirements of sharks have been given much less attention, although there are some data available on the metal concentrations in the tissues of elasmobranchs (Irwin \& Davenport 2002, McMeans et al. 2007, De Boeck et al. 2010). Apart from recent work on gastric handling of salts in sharks (Anderson et al. 2010) and incidental use of oral salt loading in physiological studies (e.g. MacKenzie et al. 2002), the dietary metal intakes and mineral nutritional requirements of most shark species are unknown.

The lemon shark offers a potentially good model of shark nutrition because it has been well studied compared to other species, with information available on diet preference, daily ration, feeding ecology and behaviour (Wetherbee et al. 1990, Morrissey \& Gruber 1993, Sundström \& Gruber 1998, Newman et al. 2010). Lemon sharks are primarily piscivorous predators that are capable of selective feeding when environmental conditions and prey abundance are favourable (Newman et al. 2010). Juvenile lemon sharks demonstrate habitat selection, and prefer shallow, warm water with rock or sandy substrate (Morrissey \& Gruber 1993). The lagoons at Bimini, Bahamas typify this habitat. Juvenile lemon sharks there feed predominantly on teleosts, which make up $\sim 95 \%$ of the diet, and the remainder is comprised of crustaceans and the occasional cephalopod or elasmobranch prey (Wetherbee et al. 1990, Newman et al. 2010). The locally abundant mojarra (Gerreidae) are the major prey of lemon sharks at Bimini (Newman et al. 2010), where the sharks have a small home range and benthic feeding patterns (Randall 1967, Newman et al. 2007). Eventually, the sharks mature and move from the shallow lagoons to open sea where the adults are able to feed on larger and more diverse prey (Wetherbee et al. 1990).

Lemon sharks are a protected species that grow to large size, which makes the conventional method of a triplicated fish nutrition trial to determine the feed requirements impractical. Instead, the approach is to collect the stomach contents of sharks captured in the wild to identify the prey species and mass of food eaten (e.g. Newman et al. 2010). Then prey species in the environment are sampled and analysed for their nutritional value, so that nutrient or energy intake may be calculated (e.g. Wetherbee et al. 1990). However, nutritional studies on wild animals are also confounded by other environmental factors, such as temporal and spatial patterns in the availability or nutritional quality of the prey species (Lawson et al. 1998), or abiotic factors such as temperature or salinity. However, lemon sharks and other lamnid sharks are able to partly control body temperature, so this is less of an issue.

In this study, the field sites were selected at Bimini, Bahamas to enable some consideration of the environmental factors. The lagoon that comprises the North Sound of Bimini is no more than 2 to $3 \mathrm{~m}$ deep, except within channels. It thus has restricted tidal flow and is subject to more pronounced seasonal salinity (dilution in the wet season) and temperature variations compared with the adjacent South Bimini, which is a more exposed site open to the sea. In addition, the North Sound has suffered anthropogenic impact with removal of over $30 \%$ of the mangrove fringe and mobilisation of sediment deposits (see Newman et al. 2007 for a detailed habitat description). Jennings et al. (2008) suggest this may contribute to less diverse bottom level species in the North Sound. We recently detailed the stomach contents and prey preference of juvenile lemon sharks at these locations (Newman et al. 2010). This included collecting specimens of the prey species from the environment at the same time that the sharks were sampled. The primary aim of the current study was to conduct a detailed nutritional trace element analysis of these prey items to provide detailed estimates of dietary essential metal intake in wild sharks. In addition, the energy content and proximate composition (protein, fat, ash, carbohydrate) of each prey species was also measured so that any changes in whole body metals could be interpreted against the general nutritional profile. The data on energy and protein content also add to the sparse literature on estimates of energy intake for sharks. Finally, sorting of the data by season (wet versus dry) and location (North versus South Sound) enabled an indication of the importance of environment or location in the overall nutritional intake. 


\section{MATERIALS AND METHODS}

Study site and sampling protocol. Known prey species of juvenile lemon sharks were collected from Bimini, Bahamas, located 40 nautical miles due east of Miami, Florida $\left(25^{\circ} 44^{\prime} \mathrm{N}, 79^{\circ} 16^{\prime} \mathrm{W}\right)$. A total of 415 samples were recovered for nutritional analyses based on their relative importance to the diet of lemon sharks (Newman et al. 2010). The Index of Relative Importance (\% IRI) values used were those calculated in Newman et al. (2010) from original ingested weight using a precise bone regression technique (\% IRI $=[\%$ number $+\%$ weight] $\times \%$ occurrence). Collections from 2 ecologically contrasting locations, North Sound and South Bimini, took place during wet and dry seasons between March 2000 to March 2003 (Newman et al. 2010, see Newman et al. 2007 for detailed information on the collection sites, general ecological conditions and prey communities at Bimini). Table 1 lists prey items taken from juvenile lemon sharks, including biometric information, condition factors and the number of samples analysed.

Prey of lemon sharks were collected from mangroves using block nets; and from seagrass using seine nets, trawl, and gillnets as described in Newman et al. (2010). Briefly, seine and block nets were $75 \mathrm{~m}$ long ( $2 \mathrm{~m}$ deep with a $5 \mathrm{~mm}$ mesh), and the trawl opening was $1 \times 0.5 \mathrm{~m}$ with a $5 \mathrm{~mm}$ mesh. Following collection, all samples were identified to species and weighed ( $\pm 0.1 \mathrm{~g}$, Ohaus Scout scales; $\pm 1 \mathrm{~g}$ for large organisms). Measurements $(\mathrm{mm})$ were taken of fork length (FL) and/or total length (TL) or carapace width (CW) according to species (Newman et al. 2010). Samples were oven dried to a constant weight, roughly ground in a clean pestle and mortar, then stored in air-tight $20 \mathrm{ml}$ vials until analysis. Samples were then analysed for trace element, energy, ash, lipid, protein and carbohydrate content (see below).

Trace element analyses. Trace element concentration of whole prey items of lemon sharks was determined using inductively coupled plasma-optical emission spectrometry (ICP-OES; VARIAN 725-ES) following the method of Handy et al. (1999) with minor modifications. Analar grade reagents or above were used for all solutions, and spectrophotometric grade reagents were used for analytical standards. Analysis focused on the nutritionally required elements most important to the survival of most complex organisms (NRC 1993) including $\mathrm{Cu}, \mathrm{Fe}, \mathrm{Zn}, \mathrm{Mn}$ and the major electrolytes $\mathrm{Na}, \mathrm{K}, \mathrm{Ca}, \mathrm{Mg}$. One percent Ytrium (Y) was used as an internal standard, and samples were matrix matched with blanks and calibration standards. Samples ( 1 g dry weight) were digested in $5 \mathrm{ml}$ of concentrated Aristar grade nitric acid in a water bath at $40^{\circ} \mathrm{C}$ using $20 \mathrm{ml}$ polythene screw-top digestion vials (VWR International). Samples were allowed to cool overnight, and then diluted to $18 \mathrm{ml}$ with deionised water. In some cases where dry weights were $<1 \mathrm{~g}$, then $1 \mathrm{ml}$ of acid was used in the digestion, and samples were diluted to $5 \mathrm{ml}$ instead. Instrument calibrations were performed using acidified, serial dilutions of the relevant certified standard. Top standards were $4 \mathrm{mg} \mathrm{l}^{-1}$ for $\mathrm{Cu}, \mathrm{Fe}$ and $\mathrm{Zn} ; 200 \mathrm{mg} \mathrm{l}^{-1}$ for $\mathrm{Mg}, \mathrm{Ca}$ and $\mathrm{Na}$; $0.4 \mathrm{mg} \mathrm{l}^{-1}$ for $\mathrm{Mn}$; and $400 \mathrm{mg} \mathrm{l}^{-1}$ for $\mathrm{K}$. Standards were analysed at the beginning of each run, and checked every 10 samples. Certified reference material DORM-2 (Dogfish Squalus acanthias muscle tissue, National Research Council Canada) was analysed using identical methods, and gave good recoveries (all within $100 \pm 10 \%$ ). In addition, spiked sample recoveries from analysis of $\mathrm{Ca}, \mathrm{Cu}, \mathrm{K}$ and $\mathrm{Zn}$ at $50 \mu \mathrm{g}$ $\mathrm{ml}^{-1}$ in Sphyraena barracuda tissues were all within $102 \pm 4 \%$ (mean $\pm \mathrm{SE}_{;} \mathrm{n}=5$ per element), indicating good recovery of metals from our digestion procedure and subsequent analysis.

Proximate composition analyses. Key species in the diet of lemon sharks (see \% IRI in Newman et al. 2010) were selected for proximate composition analyses using the standard method for whole fish (AOAC 1995). A total of 60 samples were analysed; from 9 species of fish and 3 species of crab (5 to 6 replicates of each species). Samples were initially cut into small pieces with clean scissors, then ground to a fine powder using an electric grinder, or pestle and mortar as appropriate. Carcass protein was determined by the Kjeldal digestion method (AOAC 1995). Briefly, 85 to $265 \mathrm{mg}$ of dry sample (in triplicate) was digested with a Kjeldal tablet (KJELTABS TCT, Thompson \& Capper) diluted up to $25 \mathrm{ml}$ with $0.1 \mathrm{M} \mathrm{H}_{2} \mathrm{SO}_{4}$. Samples were heated (Kjeldatherm digestion block) using the following manifold temperatures: $105^{\circ} \mathrm{C}$ for $15 \mathrm{~min}, 225^{\circ} \mathrm{C}$ for $60 \mathrm{~min}, 380^{\circ} \mathrm{C}$ for $45 \mathrm{~min}$, then lowered to $105^{\circ} \mathrm{C}$. Samples were then distilled (Gerhardt Vapodest 40 ), and converted to \% protein using a conversion factor of 6.25 in accordance with AOAC (1995). Recovery of protein from casein reference material (Standard materials, International Feed Number: 5-01-162) analysed on each sample run was $101.41 \pm 0.25 \%(n=6)$. To prevent foaming, silicone anti-foaming agent $(1 \mathrm{~g}$, Fisher Scientific) was added to crustacean samples prior to analyses. Lipid was determined by anhydrous ether extraction (Soxtec System HT Extraction Unit) according to AOAC (1995), using 325 to 1060 mg samples (in triplicate). Ash was determined by the direct method (AOAC 1995) using 2 to 3 repeated measures on each sample and an initial dry weight of around $500 \mathrm{mg}$. Samples were heated to $550^{\circ} \mathrm{C}$ in a muffle furnace for a minimum of $8 \mathrm{~h}$, and the resulting ash was weighed. Energy content of ground tissue was determined according to AOAC (1995) using a bomb 


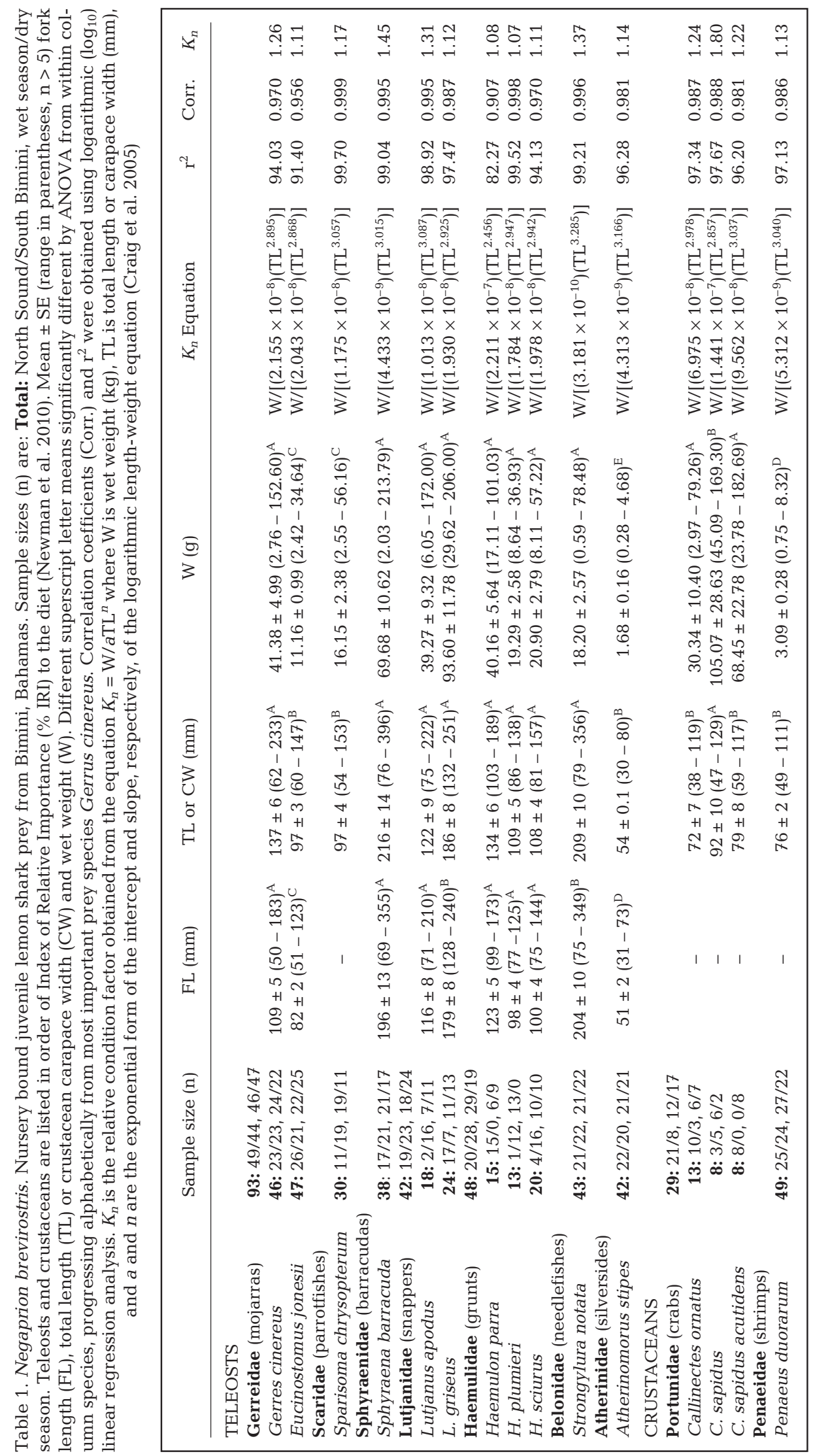


calorimeter (PARR 1356) pressurised with 30 bar $\mathrm{O}_{2}$. Briefly, 879 to $1170 \mathrm{mg}$ of powdered sample was pressed into a pellet and measured in the calorimeter (in triplicate, or duplicate for small animals). The water jacket on the instrument was filled to $2000 \pm 0.500 \mathrm{~g}$ with distilled water, 2 to $3^{\circ} \mathrm{C}$ lower than room temperature. Bucket water weight was checked after every run, and changed every 4 to 5 tests. The remaining sample following bomb calorimetry was calculated as $99.746 \pm 0.157 \%$ ash (mean $\pm \mathrm{SE}, \mathrm{n}=16$ ) .

Statistics and calculations. Statistics were conducted using Statgraphics 5.1. After descriptive statistics and a variance check (Cochran's $C$-test), data for each parameter (macronutrient, energy or metal) were analysed using 1-way Analysis of Variance (ANOVA) for season (wet versus dry), and location (North Sound versus South Bimini), after checking that body size did not affect the data for individual species by season or location; and in 3 rare dietary items where this did occur, body size or other morphometrics of the prey was used as a covariate in the ANOVA. Differences in metal concentration by species (regardless of season or location) were similarly analysed by ANOVA. In all cases, the default Fisher's Least Squares Differences (LSD) posthoc test was used to identify the individual differences in the ANOVA. Where the variance check failed, data were transformed; where data were non-parametric and could not be transformed the Kruskal-Wallis test was used. All statistical analysis used the default rejection level of $p=0.05$. In the text, all $p$-values that are reported are for ANOVAs, unless otherwise stated. Relative condition factors in Table $1\left(K_{n}\right)$ were obtained using the methods of Craig et al. (2005): $K_{n}=\mathrm{W} / \mathrm{TL}^{n}$ where $\mathrm{W}$ is wet weight $(\mathrm{kg}), \mathrm{TL}$ is total length or carapace width (mm), and $a$ and $n$ are the exponential form of the intercept and slope, respectively, of the logarithmic length-weight equation for linear regression. In addition, Pearson correlation analysis was used to identify any possible correlations between metals where these are expected (e.g. Fe and $\mathrm{Cu}$ interactions in the tissue, see Carriquiriborde et al. 2004).

The data on nutritional composition and metal content of prey items were used to calculate the daily nutrient or metal intakes of lemon sharks as follows. The average body weight of the lemon shark $(1.85 \mathrm{~kg})$ and a daily ration of the average shark at Bimini (24.84 g, i.e. $1.34 \%$ of body weight) were calculated from the original data set used in the Newman et al. (2010) study. Then, using the measured \% IRI of prey species of the shark, the amount of each prey item in the diet was calculated on a wet weight basis, and converted to dry weight using the measured \% moisture content of each species as appropriate. Then, the absolute calculated amount ( $g$ dry weight) of each prey item was multiplied by the concentration (e.g. $\mathrm{mg} \mathrm{g}^{-1}$ dry weight) of the relevant nutrient to obtain the amount ingested for an average shark. Note that data by season, location, and dietary intakes calculated are shown to family level because the resolution of identifying prey from digest remains or bones in the shark's stomach was only to this level (Newman et al. 2010). In dietary analysis by Newman et al. (2010), some rare dietary items were not identified, and therefore were not analysed for nutritional content in the current study. These accounted for $3 \%$ of total dietary intake and were considered to have negligible impact on the diet as a whole. Therefore, in the current study, results for $97 \%$ of the diet were multiplied by $3 \%$ to provide an estimate for $100 \%$ of the daily nutritional intake. Dietary intakes are expressed as an absolute amount (grams or joules) for a typical $1.85 \mathrm{~kg}$ shark, and where appropriate this is sometimes expressed as a percentage of the total daily intake. In order to add clarity to the data of each type of prey item, intakes are presented at family level rather than species.

\section{RESULTS}

\section{Metal contents of prey items}

Metal concentrations varied between all 15 species of lemon shark prey (Table 2). The most common prey of the lemon shark, yellow fin mojarra, contained some of the highest trace element concentrations of all the teleost species analysed (Table 2). Yellow fin mojarra showed significantly higher Fe and Mn concentrations than all other fishes, and the highest Fe of all the animals examined. Zn was also significantly higher in both mojarras (Gerreidae), yellow fin and slender mojarra Eucinostomus jonesii, than in all other fishes except silversides (Atherinidae; Atherinomorus stipes) and needlefishes (Belonidae; Strongylura notata). Slender mojarra had $\mathrm{Zn}, \mathrm{Ca}$, and $\mathrm{Na}$ concentrations that were similar to yellow fin mojarra, although both Fe and Mn were significantly higher in the yellowfin within the mojarra family (Table 2). Similar findings applied to $\mathrm{Na}$ and $\mathrm{Ca}$ between slender and yellow fin mojarra. Among the fishes, silversides and needlefish had the highest $\mathrm{Na}, \mathrm{Ca}$ and $\mathrm{Mg}$, and barracuda (Sphyraenidae; Sphyraena barracuda) had the highest $\mathrm{K}$. Not surprisingly, concentrations of the minerals $\mathrm{Ca}$, $\mathrm{Cu}, \mathrm{Na}, \mathrm{Mg}$ and $\mathrm{Mn}$ were generally higher in crustaceans than teleosts (Table 2). Pink shrimp (Penaeidae; Penaeus duorarum) had the highest Na concentration of all animals, and a $\mathrm{K}$ concentration comparable to many of the teleost fish. Swimming crabs (Portunidae; Callinectes spp.) contained the highest $\mathrm{Ca}$ and $\mathrm{Mg}$ of all the prey species analysed, but $\mathrm{K}$ was generally half that of fishes (Table 2). The crabs, 
as expected from their respiratory pigments, contained higher $\mathrm{Cu}$ and significantly lower Fe compared to the teleosts (Table 2). The crabs were a particular good source of Mn, yet parrotfish (Scaridae; Sparisoma chrysopterum) and yellow fin mojarra contained more than the most com- monly predated crustacean, Callinectes ornatus.

Comparison of concentrations of different metals within each species did produce correlations that were not random (i.e. $>5 \%$ ), but most gave $\mathrm{r}^{2}$ values of $20 \%$ or much less. Nonetheless, there were some notable exceptions. For example, $\mathrm{Zn}$ negatively correlated with $\mathrm{Cu}$ (e.g. barracuda: $\mathrm{Zn}=83.3696-39.4415$ / $\mathrm{Cu}, \mathrm{r}^{2}=37.57$, correlation coefficient $=$ -0.61 ), and $\mathrm{Fe}$ positively with $\mathrm{Cu}$ (e.g. parrotfish: $\mathrm{Fe}=83.0521-62.426 / \mathrm{Cu} \mathrm{r}^{2}=$ 40.18 , correlation coefficient $=-0.63$ ) except in yellow fin mojarra, and crustaceans. Several elements correlated positively with $\mathrm{Mn}$ (e.g. parrotfish: $\mathrm{Ca}=$ $15.6095+51.4775 \times \mathrm{Mn}, \mathrm{r}^{2}=77.64$, correlation coefficient $=0.88 ; \mathrm{Fe}=32.7835+$ $36.4913 \times \mathrm{Mn}, \mathrm{r}^{2}=40.77$, correlation coefficient $=0.64$ ). There were no body size effects between locations or seasons at the level of species.

\section{Spatial variation in metal concentrations of prey items}

There were a number of statistically significant differences between the metal concentrations in the animals from the North Sound compared to South Bimini (38 out of 80 comparisons were different, Fig. 1). When location differences occurred in the major electrolytes, these tended to be higher in animals from South Bimini. There were only a few location differences in whole body Na. Grunts, parrotfish and shrimps showed statistically significant higher concentrations of Na in South Bimini compared to the North Sound. Barracuda and silversides contained higher $\mathrm{K}$ concentrations in South Bimini compared to the North Sound (Fig. 1). The mojarra, parrotfish, and most species of snappers also showed higher Ca concentrations in South Bimini but, notably, silversides

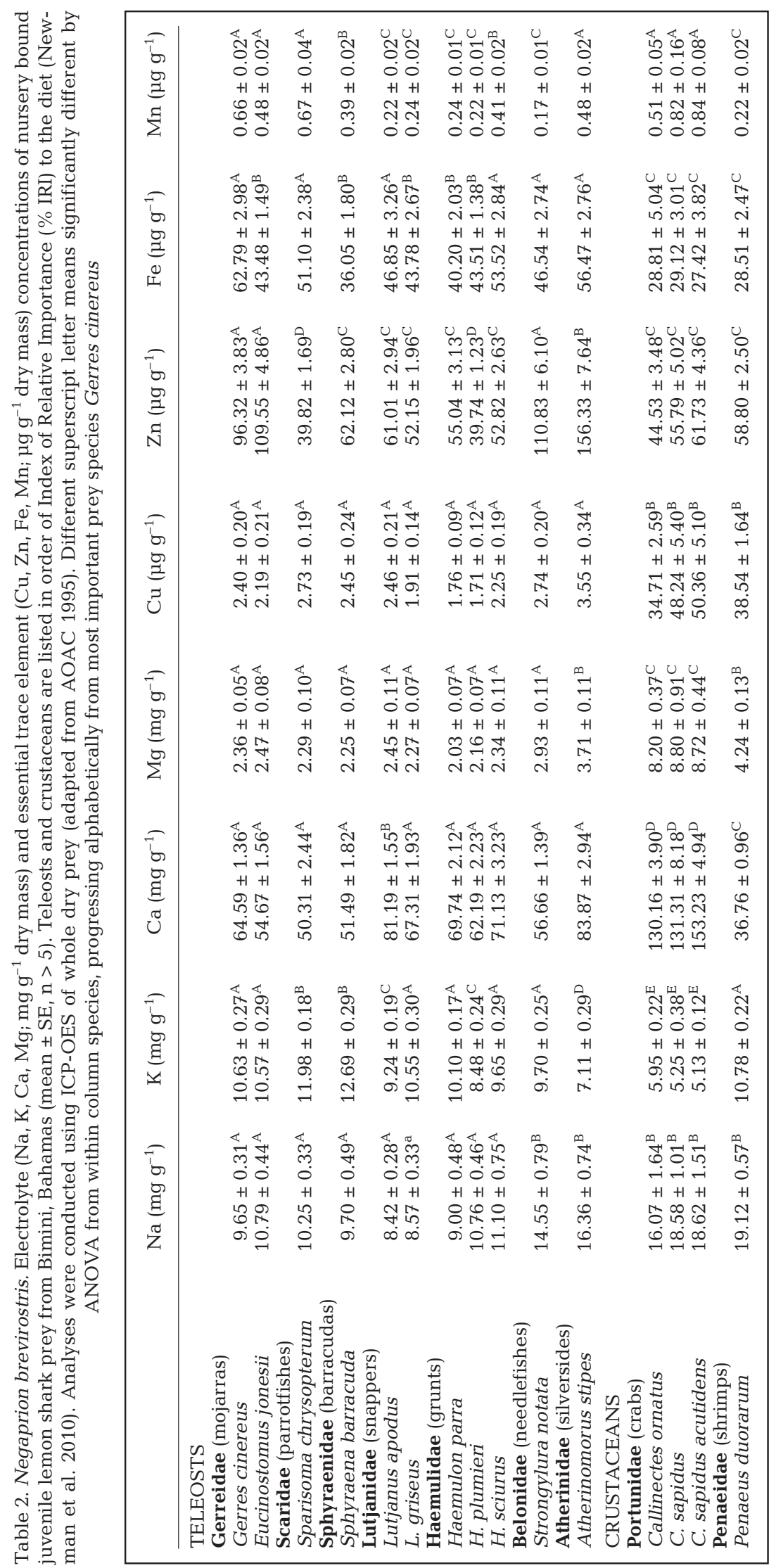




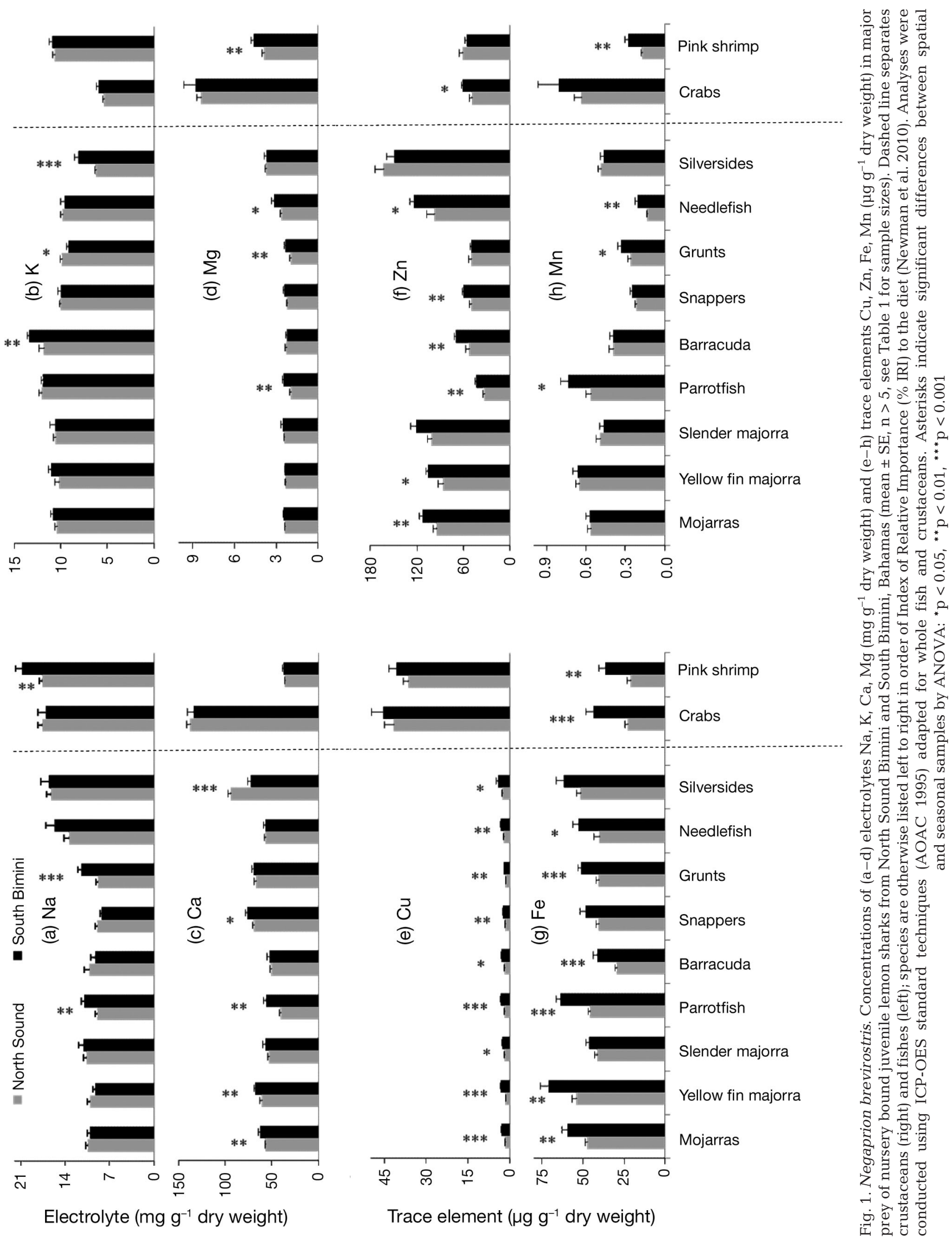


had lower Ca in South Bimini. In the few species where location differences in Mg occurred, all showed higher concentrations in South Bimini (Fig. 1d). The trace elements showed more location effects than the bulk electrolytes. In particular, all fish species showed higher $\mathrm{Cu}$ concentrations in South Bimini compared to the North Sound (Fig. 1e), as did many of the fishes for Zn (Fig. 1f). There were also some strong differences in Fe concentration between locations, with $\mathrm{Fe}$ concentration being higher in all animals from South Bimini except slender mojarra, snappers, and silversides, for which no location effects could be detected (Fig. 1g). For Mn, only parrotfish, some grunts, needlefish, and pink shrimp showed a location effect, with higher concentration in specimens from South Bimini.

\section{Seasonal variation in the metal concentrations of prey items}

There were some seasonal effects on metal concentrations and, when these occurred, metals were usually higher in animals collected during the dry season (Fig. 2). Yellow fin mojarra showed an increase of $\mathrm{Na}$ in the dry season, but needlefish, silversides and pink shrimp showed the reverse (Fig. 2a). Yellow fin mojarra showed a decrease of $\mathrm{K}$ in the dry season, but some grunts, needlefish and silversides showed increases (Fig. 2b). Grunts showed the biggest seasonal increase of $\mathrm{Ca}$ in the dry season (Fig. 2c). Conversely, where seasonal effects in Mg occurred, concentrations were generally lower in animals from the dry season (Fig. 2d). There were no seasonal effects on $\mathrm{Cu}$, except a small increase in $\mathrm{Cu}$ concentrations in grunts in the dry season (Fig. 2e). Only snappers and shrimps showed a seasonal effect for Fe (Fig. 2g). Among the trace metals, the most pronounced seasonal effects were found for Zn (Fig. 2f), with yellow fin mojarra, snappers, barracuda, grunts and crabs showing higher concentrations in the dry season. Yellow fin mojarra and grunts also showed some large increases in $\mathrm{Mn}$ in the dry season (Fig. 2h).

\section{Proximate carcass composition and energy content}

The teleost fish gave higher energy values than the crustaceans and, among the fishes, highest values were found in the slender mojorra, followed by the barracuda (Table 3 ). Slender mojarra

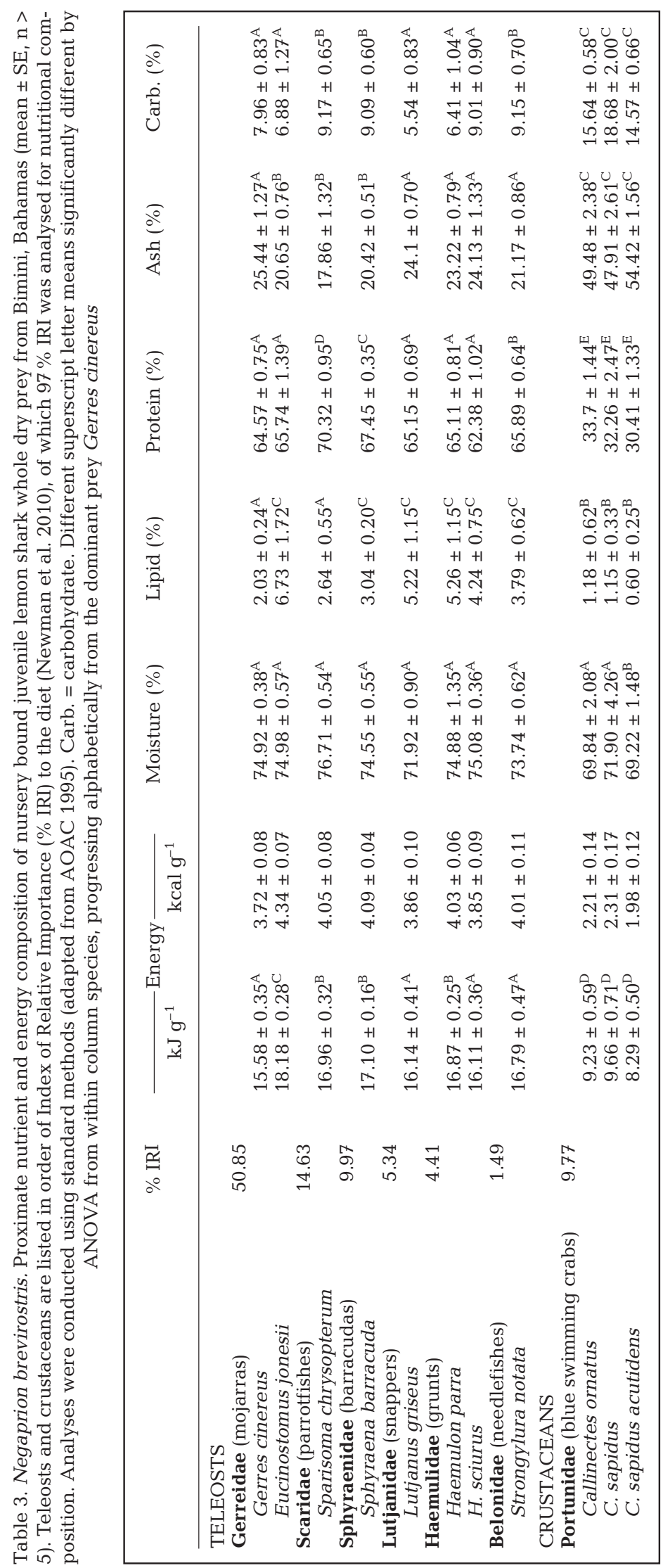




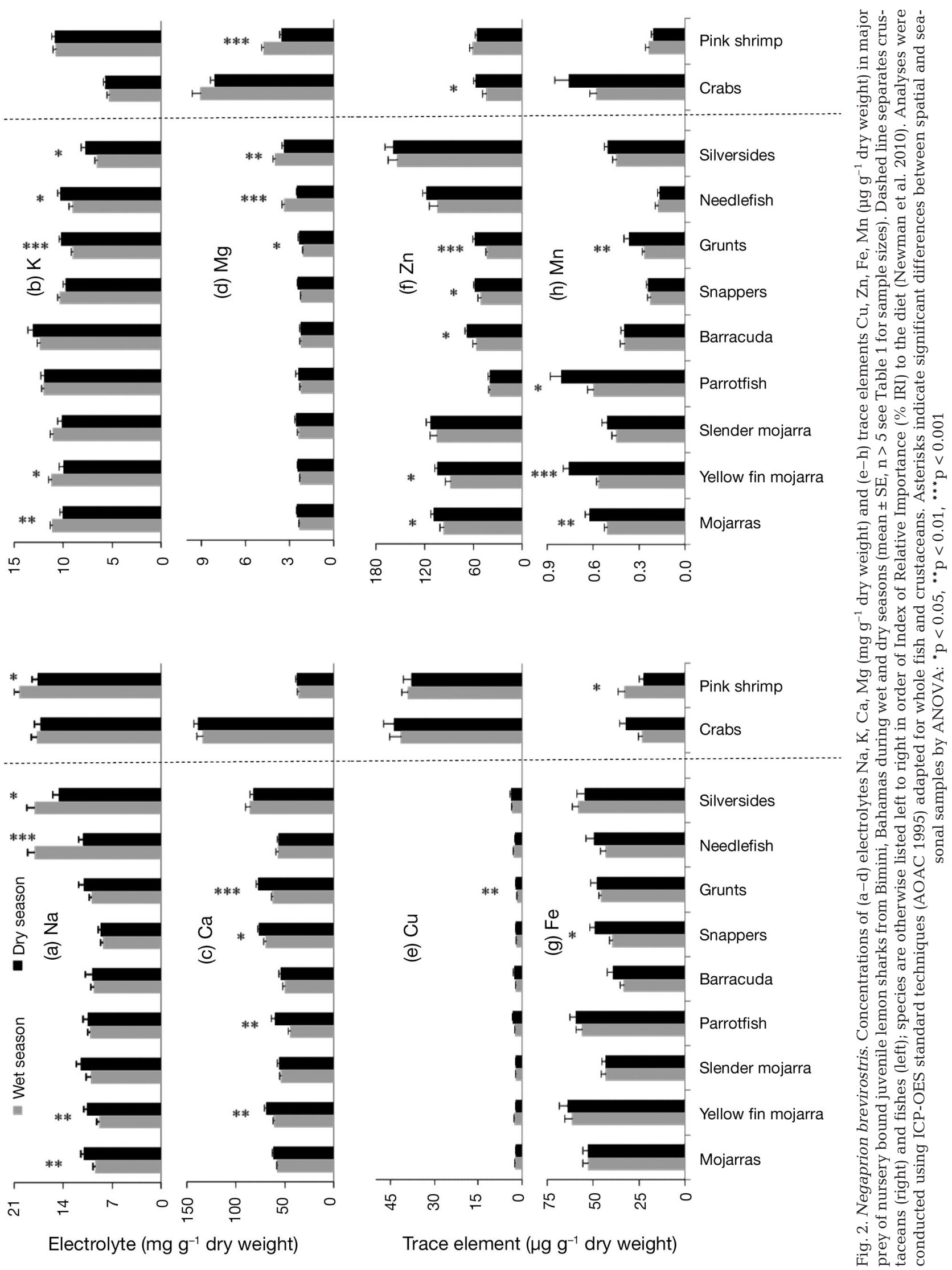


had the highest lipid contents of all the animals examined, although the grunts and snappers were also a good source of lipid (Table 3). The crabs provided the richest source of carbohydrates and ash, but were low in protein compared to teleost prey items. Of the fishes, the parrotfish provided the most protein on a percent of carcass basis (Table 3). The mojarras and parrotfishes generally had slightly higher moisture contents than the other fishes (Table 3 ). There were not enough individuals from each species to do a comparison of proximate composition and energy content by location (North Sound versus South Bimini) or season (wet versus dry). An analysis of the data pooled by species showed no location effect on protein, lipid, ash or carbohydrate content of the prey (ANOVA: $p>0.05$, data not shown). Similarly, there were no seasonal effects on proximate composition, except an overall $3 \%$ increase in carbohydrate in the wet season (Kruskal-Wallis: $\mathrm{p}=$ 0.01 , data not shown).

\section{Calculated daily nutritional intake}

Table 4 displays the calculated daily nutritional intake of the macronutrients (protein, fat and carbohydrate), energy, and the intake of metals obtained from the different prey items. The data are illustrative for an average $1.85 \mathrm{~kg}$ juvenile lemon shark from Bimini with an average ration size of $24.84 \mathrm{~g} \mathrm{~d}^{-1}$. Then, using data on prey preference of lemon sharks, an estimate of the gross proportions of the diet was calculated (Fig. 3). Notably, the diet was mostly protein $(61.9 \%)$, and much of the remainder is ash $(24.9 \%)$ which includes the mineral component of the diet. Lipid is only $4.6 \%$ of the diet, and carbohydrates are also a low proportion $(8.6 \%$, Fig. 3). Calculated absolute values of dietary intake for a $1.85 \mathrm{~kg}$ lemon shark were: $397.06 \mathrm{~kJ}$ energy, $15.34 \mathrm{~g}$ protein, $6.17 \mathrm{~g}$ ash, $1.15 \mathrm{~g}$ lipid, and $2.14 \mathrm{~g}$ carbohydrate per day (Table 4). The average lemon shark ingested $\sim 1 \mathrm{mg}$ or less of the trace metals, but much more of the bulk electrolytes, and $>1 \mathrm{~g}$ of Ca each day (Table 4). For the metals, most of the elemental content of the daily ration is $\mathrm{Ca}(6.6 \%)$ and, of the metals measured, Ca accounted for $73 \%$ of the entire metal intake by mass. $\mathrm{Na}$ and $\mathrm{K}$ contributed $1 \%$ of the daily ration, respectively. Magnesium was $0.3 \%$ of the daily ration, and the trace elements together contributed only $0.01 \%$ of the daily ration (Fig. 3).

The stomach contents of sharks can often only be usefully analysed to family level (see Newman et al. 2010). When the daily nutritional intake is considered according to the importance of each family of prey in the diet, it is clear that the mojarras $(50.85 \%$ of the daily ration) contribute most of the major nutrients and

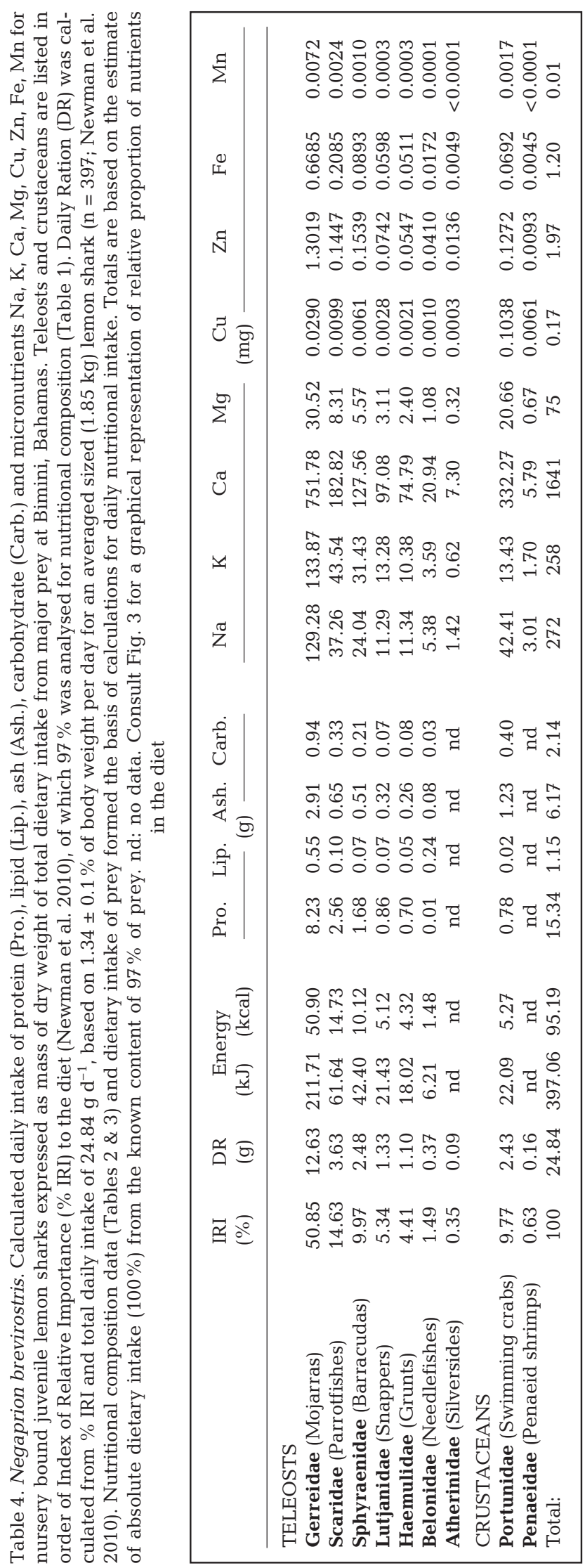




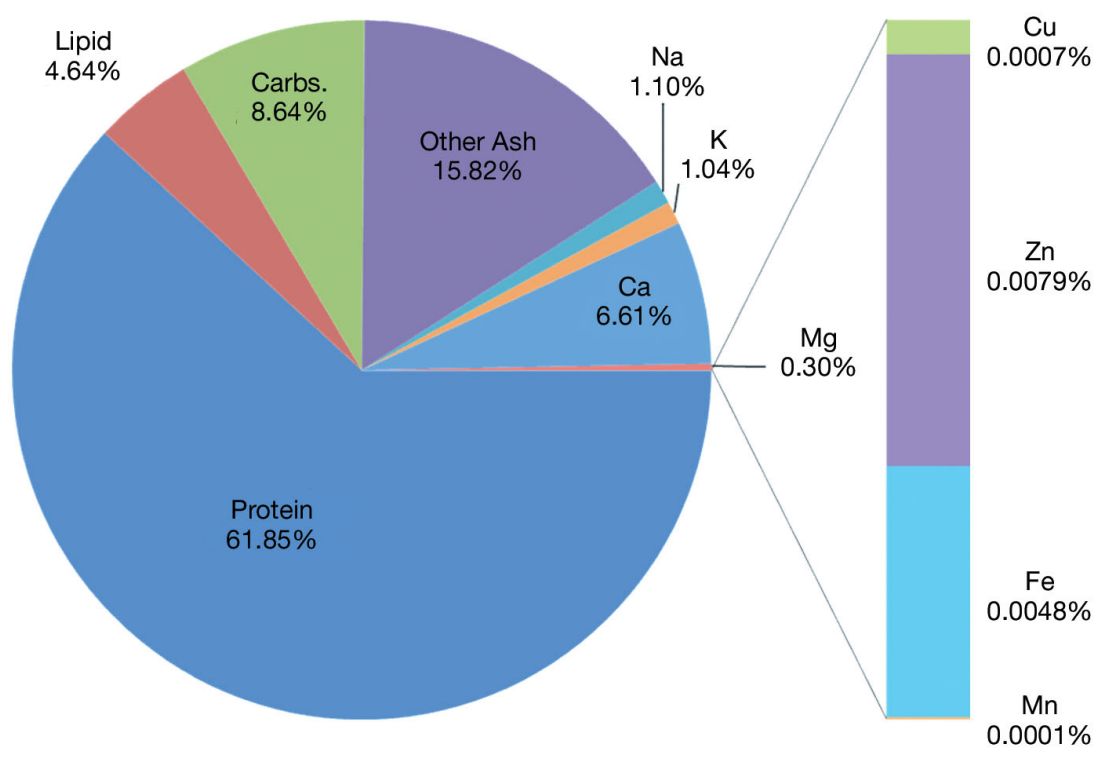

Fig. 3. Negaprion brevirostris. Calculated daily intake of macro- and micronutrients as a percentage contribution to the diet of nursery bound juvenile lemon sharks. Daily intake calculations were based on the composition of whole prey (Tables 2 \& 3), Index of Relative Importance (\% IRI) to the diet (Newman et al. 2010), occurrence (Table 4) and total daily ration estimates for the average sized nursery bound juvenile lemon sharks at Bimini, Bahamas, calculated as $24.84 \mathrm{~g} \mathrm{~d}^{-1}$ based on $1.34 \pm 0.1 \%$ of body weight per day for a $1.85 \mathrm{~kg}$ lemon shark ( $\mathrm{n}=397$; Newman et al. 2010). Elements also contribute to the total ash content (total intake of ash $=24.88 \%$ ) items collected in the field at the same time/locations as the stomach contents of the sharks (Newman et al. 2010). Data sets on the macronutrient and metal composition of carcasses of tropical fish are relatively limited compared to temperate species. The data shows that the metal content of the tropical species of fish and crustaceans eaten by lemon sharks are broadly similar to the temperate species used in aquaculture and those well known in fish nutrition. Calculation of a typical daily nutritional intake showed that the lemon shark eats a very lean, high protein diet and that the mineral intake is dominated by Ca. Juvenile lemon sharks get most of their daily nutritional intake from eating yellow fin mojarras, but parrotfish provide the main intake of lipid. Notably although invertebrates are less frequent in the diet of lemon sharks, they do provide an important contribution to the mineral intake; especially $\mathrm{Cu}, \mathrm{Ca}$, and $\mathrm{Mg}$. minerals to the daily diet of lemon sharks at Bimini (Table 4). Even animals with high nutritional value on a carcass composition basis, had little effect on the overall daily nutritional profile when the \% IRI was low. For example, snappers contained a high level of energy compared to other species $\left(16.14 \pm 0.41 \mathrm{~kJ} \mathrm{~g}^{-1}\right)$ yet, at little more than 5\% IRI, contributed only $21.43 \mathrm{~kJ} \mathrm{~d}^{-1}$ or $5 \%$ of the daily energy intake. However, notably, needlefish provided $0.24 \mathrm{~g}$ of the $1.15 \mathrm{~g}$ of daily lipid intake equal to $20 \%$ of the daily lipid intake, despite this family making up only $1.5 \%$ of the diet (Table 4). The mojarras dominated the daily mineral intake, but $20 \%$ of the daily Ca (332 $\mathrm{g}$ out of $1641 \mathrm{~g})$ and nearly $28 \%$ of the daily $\mathrm{Mg}$ (20.7 $\mathrm{g}$ out of $74.5 \mathrm{~g}$ ) was obtained from swimming crabs (Table 4). Notably, 63 and $13 \%$ of the daily $\mathrm{Cu}$ and Mn intake, respectively, was also obtained from swimming crabs (Table 4). Despite being only $10 \%$ of the daily ration by family, the crabs therefore provided an important contribution to the overall trace metal intake of sharks.

\section{DISCUSSION}

To our knowledge this study is one of the first to provide detailed trace element nutritional information on the prey items of juvenile lemon sharks, and for prey

\section{Metal concentrations in prey items and metal intake by lemon sharks}

There are relatively few reports of the tissue concentrations of the major electrolytes (i.e. $\mathrm{Na}, \mathrm{K}, \mathrm{Ca}, \mathrm{Mg}$ ) in tropical species of fish, compared to the wealth of data on temperate species (for reviews see: Holmes \& Donaldson 1969, electrolytes in the body; Eddy 2009, Na; Salman 2009, Na; Flik et al. 2009, Ca; Bijvelds et al. 1998, Mg). For the fish species in Table 2 there appear to be no previous reports detailing the major electrolyte composition of the whole carcass. However, the whole body $\mathrm{Na}$ concentration in this study (8-16 $\mathrm{mg} \mathrm{g}^{-1}$, Table 2) were, as expected, slightly higher than that of rainbow trout in freshwater (e.g. 0.7-1 $\mathrm{mg} \mathrm{g}^{-1}$, Salman 2009); but close to trout in seawater ( 2.6 $\mathrm{mg} \mathrm{g}^{-1}$, Eddy \& Bath 1979) and similar to marine teleosts (e.g. sea bream: $9.2 \mathrm{mg} \mathrm{g}^{-1}$, Van Anholt et al. 2004). Whole body $K$ appears to be rarely reported in fish, but the concentrations here (7-12 $\mathrm{mg} \mathrm{g}^{-1}$, Table 2) were similar to freshwater trout ( $6 \mathrm{mg} \mathrm{g}^{-1}$, Eddy \& Bath 1979). Calcium concentrations in fish in this study (50-84 $\mathrm{mg} \mathrm{g}^{1}$, Table 2) are similar to those reported for marine scorpion fish (Sebastiscus marmoratus: $\sim 55 \mathrm{mg} \mathrm{g}^{-1}$, Hossain \& Furuichi 2000). Carcass Mg concentration in fish depends especially on the amount of hard tissue (scales, bones) which can 
contribute $70 \%$ of the total $\mathrm{Mg}$ pool (Bijvelds et al. 1998). In freshwater-adapted tilapia Oreochromis mossambicus the skeletal muscle contains $\sim 1.4 \mathrm{mg} \mathrm{g}^{-1}$, and the bone $3.1 \mathrm{mg} \mathrm{g}^{-1}$ of $\mathrm{Mg}$, which are broadly similar to the values for whole fish in this study $\left(\sim 2 \mathrm{mg} \mathrm{g}^{-1}\right.$, Table 2). For crustaceans, the mineral contents are often reported just for the edible parts of the flesh and exclude the exoskeleton (Gökoðlu \& Yerlikaya 2003, Naczk et al. 2004). However, the analysis here also included the exoskeleton, and the values for $\mathrm{Mg}$ and Ca (Table 2) are at least broadly similar to reports for the whole body of Callinectes spp. when tissue wet weight is taken into account (Neufeld \& Cameron 1992).

Similar considerations apply to the trace metals (Fe, $\mathrm{Cu}, \mathrm{Zn}, \mathrm{Mn}$ ). In fish, the $\mathrm{Fe}$ concentrations (36-52 $\mu \mathrm{g} \mathrm{g}^{-1}$, Table 2) in our study are similar to reports for trout carcass (11-41 $\mu \mathrm{g} \mathrm{g}^{-1}$, Carriquiriborde et al. 2004). Copper and $\mathrm{Zn}$ concentrations ( $\mathrm{Cu} 1-3 \mu \mathrm{g}$ $\mathrm{g}^{-1}$, Zn 39-156 $\mathrm{gg} \mathrm{g}^{-1}$; Table 2) are also similar to previous reports for marine fish (grey mullet Chelon labrosus: $\mathrm{Cu} \sim 7 \mu \mathrm{g} \mathrm{g}^{-1}, \mathrm{Zn} \sim 43 \mu \mathrm{g} \mathrm{g}^{-1}$; Baker et al. 1998). The carcass Mn concentrations for wild fish (0.1-0.7 $\mathrm{g} \mathrm{g} \mathrm{g}^{-1}$, Table 2) are lower than those for marine fish fed a normal Mn supplement in aquaculture (juvenile groupers Epinephelus coioides: 4-10 $\mathrm{gg} \mathrm{g}^{-1}$, Ye et al. 2009), but are comparable to reports for Atlantic salmon Salmo salar ( 0.2 $\mu \mathrm{g} \mathrm{g}^{-1}$, Maage et al. 2000). Trace metal concentrations in the crustaceans are also broadly comparable with previous reports (Scott-Fordsmand \& Depledge 1997, Gökoðlu \& Yerlikaya 2003).

The calculated electrolyte intakes for an average lemon shark (Table 4) also show some similarity with other fishes. Most teleosts require a dietary salt intake of $\sim 1 \%$ (Salman 2009) and this is at least matched by similar $\mathrm{Na}$ and $\mathrm{K}$ intakes in the lemon shark $(\sim 1 \%$, Table 4). In seawater, Flik et al. (1995) argue that dietary $\mathrm{Ca}$ has a negligible role in $\mathrm{Ca}$ metabolism in fishes, with Ca influx at the gills being more important. Seawater typically contains $10 \mathrm{mmol} \mathrm{l}^{-1} \mathrm{Ca}$ and, with elasmobranchs having a plasma Ca concentration of $\sim 4 \mathrm{mmol}^{-1}$ (e.g. Trivett et al. 2001), it would also seem that sharks could achieve their $\mathrm{Ca}$ requirements through Ca uptake at the gills. It is therefore curious that the lemon shark ingests a diet of $\sim 6 \% \mathrm{Ca}$ as dry matter. Calcium plays a role in biomineralisation of secreted bicarbonate to help maintain acid-base balance in flounder (Whittamore et al. 2010), which obtain their $\mathrm{Ca}$ through drinking seawater as part of their osmoregulatory strategy. Sharks are osmoconformers and do not normally drink much seawater, but may still need ingested $\mathrm{Ca}$ for biomineralisation processes. Alternatively, it is more likely that the $\mathrm{Ca}$ is just an incidental component of the diet not required for $\mathrm{Ca}$ homeostasis. Similar osmoregulatory arguments apply to $\mathrm{Mg}$, where $\mathrm{Mg}$ concentration in seawater is typically at $\sim 50 \mathrm{mmol} \mathrm{l}^{-1}$, but tissue normally contains only a few mmols, and therefore any dietary requirement would be negligible (Bijvelds et al. 1998, Flik et al. 2009). Nonetheless, $\sim 0.3 \%$ of the daily ration is $\mathrm{Mg}(74.49 \mathrm{mg}$ of $\mathrm{Mg}$ for $24.84 \mathrm{~g}$ of ingested food, Table 4).

The dietary trace element requirements of sharks are mostly unknown. In this study the amount of ingested Zn was $\sim 0.008 \%$ of the daily ration (Table 4 \& Fig. 3). Typical fish meals used in aquaculture contain 80 to $100 \mathrm{mg} \mathrm{Zn} \mathrm{per} \mathrm{kg}$ food (i.e. $0.001 \%$ or less of the diet, Watanabe et al. 1997). It would therefore seem that the $1.97 \mathrm{mg}$ daily $\mathrm{Zn}$ intake of the lemon sharks exceeds the minimum requirements of fish. This does not seem to be the case for the other dietary metals. Fish have a minimum dietary Fe requirement of at least $30 \mathrm{mg} \mathrm{kg}^{-1}$ of food or more $(\sim 0.03 \%$ of the ration in trout, see Carriquiriborde et al. 2004). In comparison to teleosts, the lemon shark has a low iron intake at $\sim 0.005 \% \mathrm{Fe}$ in the daily ration (Table 4 \& Fig. 3). Assuming that iron metabolism in sharks is similar to other fish, this could tentatively be interpreted as evidence that the lemon shark may be Fe deficient. Fish normally require a few $\mathrm{mg} \mathrm{kg}^{-1}$ of dietary $\mathrm{Cu}$ each day (Handy et al. 1999) and, with the lemon sharks eating only $\sim 0.1 \mathrm{mg} \mathrm{Cu}$ per day (Table 4 ), this is also at least an order of magnitude below the requirements of other fish. Little is known about $\mathrm{Cu}$ metabolism in elasmobranchs but, for spotted dogfish Scyliorhinus canicula at least, $\mathrm{Cu}$ exposure results in the expected metallothionein induction and tissue $\mathrm{Cu}$ accumulation (De Boeck et al. 2010). Thus it seems unlikely that $\mathrm{Cu}$ metabolism in sharks is vastly different from other fish, and would therefore suggest that lemon sharks are probably $\mathrm{Cu}$ deficient. Similarly, most fish need a few milligrams of Mn per day, and the Mn intake of $0.01 \mathrm{mg}$ (Table 4 ) is at least 2 orders of magnitude below the requirements of most fishes (Watanabe et al. 1997). There also appears to be no information on $\mathrm{Mn}$ metabolism in sharks, but it would be extremely unlikely that a 100-fold lower Mn intake in the lemon shark could be compensated by comparably more efficient $\mathrm{Mn}$ uptake or retention mechanisms, given that metal transporters are well conserved across species (Bury et al. 2003).

There were some seasonal and location effects on the metal contents of prey items (Figs. 1 \& 2). The reasons for the small differences in prey metal concentrations by location could relate to anthropogenic activity (e.g. building construction on the shore line) mobilising minerals into the aquatic food chain, or simply changes in geochemical cycling (e.g. by removal of vegetation, Jennings et al. 2008). Tolerable dilution during wet season could also explain the slightly lower electrolyte concentration in the tissues in the winter. 
However, these effects on overall elemental intake were mostly small and not likely to have a big nutritional impact. For example, the preferred prey, yellow fin mojarra, showed one of the biggest changes in dietary Fe intake by location (from $~ 55 \mu \mathrm{g} \mathrm{g}^{-1}$ in the North Sound to $\sim 70 \mu \mathrm{g} \mathrm{g}^{-1}$ in South Bimini, Fig. 1g). An additional $15 \mu \mathrm{g}$ Fe per $\mathrm{g}^{-1}$ of mojarra represents $\sim 198 \mu \mathrm{g}$ of extra Fe in the diet (sharks eat $12.63 \mathrm{~g}$ of mojarra per day, Table 4), or a $16 \%$ increase in the daily $\mathrm{Fe}$ intake. Nutritionally, this would bring $\mathrm{Fe}$ slightly closer to the requirements of other fish. For $\mathrm{Cu}$, the mojarra in South Bimini had about $2 \mu \mathrm{g} \mathrm{g}^{-1}$ more $\mathrm{Cu}$ than those in the North (Fig. 1e). A similar calculation yields an additional $25 \mu \mathrm{g} \mathrm{Cu}$ in the daily ration from mojarra. This would still leave the nutritional $\mathrm{Cu}$ intake for lemon sharks far below the milligram concentrations reported for other fish in the nutrition literature (Watanabe et al. 1997). Similar arguments apply to the seasonal effects. For example, mojarra showed one of the biggest increases in $\mathrm{Mn}$ in the dry season (an additional $0.3 \mu \mathrm{g} \mathrm{g}^{-1}$ of mojarra, Fig. 2h). This represents an additional $3.7 \mu \mathrm{g}$ of $\mathrm{Mn}$ in the diet $(37 \%$ rise), but this microgram increase remains far below the milligram Mn requirements of most fish (Watanabe et al. 1997).

\section{Macronutrients in prey items and estimated protein, lipid and carbohydrate intake by lemon sharks}

Practical fish diets for carnivorous or omnivorous fish in aquaculture can contain around 400 to $600 \mathrm{~g} \mathrm{~kg}^{-1}$ dry matter of crude protein , but the digestible protein may only be 30 to $40 \%$ of the dry matter (Halver 1989). These levels are set to maximise growth, and it is clear that the average lemon shark has a very high protein diet $(61.9 \%$ of dry matter, Fig. 3$)$. The lipid intake of the lemon shark is $\sim 5 \%$ of the diet (Fig. 3) and is consistent with the minimum requirement for other tropical carnivorous fish (e.g. cobia: $~ 5 \%$, Fraser \& Davies 2009). Many carnivorous fish do not have a specific minimum requirement for total carbohydrate in the diet because they are able to use protein and/or lipids as an energy source (Halver 1989). Sharks also use carbohydrate as an energy source, but the overall contribution of carbohydrates to energy metabolism is unclear (Speers-Roesch \& Treberg 2010).

However, there is a notable difference in obtaining energy from protein in elasmobranchs compared to other fish. Sharks rely more on the oxidation of amino acids for fuel (Speers-Roesch \& Treberg 2010), and this may explain the high protein intake of the lemon shark (Fig. 3). The lemon sharks at Bimini also seem to be selecting prey fish species with high carcass protein contents (around 60-70\%, Table 3). Even a well fed rainbow trout in the laboratory might have a proximate composition of $55 \%$ protein (e.g. Carriquiriborde et al. 2004), so these warm water fish have higher protein contents. However, even for wild prey, the lemon shark seems to be feeding at the upper end of the protein content range of teleosts. For example, Payne et al. (1999) analysed 13 fish species from the northeast Pacific and found a carcass protein range of approximately 40 to $60 \%$ dry mass protein, depending on species. Eder \& Lewis (2005) produced a similar range of carcass protein levels from an analysis of 27 prey fish species from the southwest Atlantic, which ranged from about 40 to $69 \%$ dry mass.

The ash and lipid contents of an adult rainbow trout in aquaculture are around 10 and $20 \%$ respectively (Carriquiriborde et al. 2004) and it is clear that the wild tropical fish eaten by the lemon shark are leaner (1-5\% lipid, Table 3); and have a higher ash content (17-25\% Table 3), probably because the fish have relatively more hard tissues (bone, scales etc.) than a trout. The yellow fin mojarra is the preferred prey of juvenile lemon sharks at Bimini (Reeve et al. 2009, Newman et al. 2010). This preference appears not be on the basis of gross nutritional value per se because several other families of fish also provide similar protein, lipid, carbohydrate and ash contents at Bimini. It would seem that the abundance in the environment, colour and shape, behaviour, or swimming speed of the mojarra (see Reeve et al. 2009, Newman et al. 2010 for discussion) are the more likely explanations for this prey choice by the lemon shark. Parrotfishes make a notable contribution to lipid intake, and the portunid crabs provided most of the $\mathrm{Cu}$ intake (Table 4), but it remains unclear if sharks will feed on particular prey items to obtain specific nutrients.

\section{Energy intake of lemon sharks}

The overall energy content of the food is also an important facet of survival for any animal. For a fish to survive in the long term, the assimilation of daily energy (after the cost of digestion and absorption), must slightly exceed daily energy expenditure (Priede 1985). In the present study the total energy intake as food for an average juvenile lemon shark (body weight $1.85 \mathrm{~kg}, 24 \mathrm{~g}$ daily ration) was calculated as $397 \mathrm{~kJ} \mathrm{~kg} \mathrm{~d}^{-1}$ (Table 4). Wetherbee \& Gruber (1993) estimate the energy absorption efficiency of the lemon shark to be around 62 to $83 \%$. Even if the lower end of this suggested absorption efficiency is used in calculations, this would give an available daily energy (after digestion and absorption costs) of around $246 \mathrm{~kJ}$. The estimated routine metabolic rate of juvenile lemon sharks of comparable weight to this study is about $106 \mathrm{~kJ} \mathrm{~d}^{-1}$ 
(Sundström \& Gruber 1998). This suggests the energy intake from food is more than enough to meet the needs of routine metabolism, and the juvenile shark has around $140 \mathrm{~kJ}$ of energy to spend on metabolic scope each day (i.e. activity in excess of routine metabolism).

DiBattista et al. (2007) argue for a bioenergetic strategy that favours slow growth of juvenile lemon sharks at Bimini. The lemon sharks are therefore not spending their metabolic scope on extra growth. Bioenergetic theory suggests that fish which keep a greater reserve of metabolic scope have a better probability of survival in the long term (Priede 1977). For example, they can use this metabolic scope to evade a predator or take a risk by chasing more nutritionally valuable prey. Lemon sharks do not seem to do the latter at Bimini. The preferred prey of yellow fin mojarra have a small home range, are slow moving, relatively inactive feeders; and are widely abundant at Bimini (Randall 1967, Newman et al. 2010). This suggests the sharks at Bimini have some 'spare' metabolic scope, but despite this, the apparent survival rates of juvenile sharks is typically around 50 to $60 \%$ (DiBattista et al. 2007). This implies that bioenergetics is not limiting the survival of sharks at Bimini, but some other factor. This, of course, could be one of the minor components of the diet such as a trace element deficiency (see above), but anthropogenic activity and its environmental implication will also be important in survival (e.g. Jennings et al. 2008). Active predators also spend the majority of their daily energy on locomotion (Priede 1985), and so the precise amount of metabolic scope in reserve each day will depend especially on daily activity patterns. Telemetry measurements of locomotion/ daily activity in lemon sharks at Bimini (Chapman et al. 2009), may help elucidate the short term daily changes in metabolic scope.

In conclusion, analysis of prey species caught in the wild shows that the calculated dietary metal intake of the lemon shark has some similarities with other fish, with $\mathrm{Na}$ and $\mathrm{K}$ being close to the $1 \%$ dietary salt intake of other fishes. Ca dominates the mineral intake of juvenile lemon sharks, but with plasma Ca levels in sharks being lower than the surrounding seawater, the role of this ingested $\mathrm{Ca}$ is unclear and may be incidental. The $\mathrm{Zn}$ intake of lemon sharks exceeds those of other fish, but the $\mathrm{Cu}, \mathrm{Fe}$ and $\mathrm{Mn}$ intakes are much lower than the minimal nutritional requirements of other fishes. The latter are more easily explained by deficiency, as it seems unlikely that sharks are orders of magnitude better at retaining metals compared to other fish. Overall, although some seasonal and location effects on the metal content of prey items were observed, this had a negligible impact on trace element nutrition. The lemon shark also eats a very high protein diet, and an energy intake that exceeds that estimated to be required for routine metabolism by more than $100 \mathrm{~kJ} \mathrm{~d}^{-1}$. Overall, the data suggest that lemon sharks have an adequate gross intake of macronutrients and energy that is consistent with their predatory tactics, but possible trace element deficiencies require clarification by detailed studies of trace metal metabolism and turnover in sharks.

Acknowledgements. The present study was supported in part by the Fish Monger Guild Award (Studentship grant) as part completion of MRes Applied Fish Biology at University of Plymouth (H. P.-W.). Many thanks to Professor Simon Davies for permitting access to the machinery in the University of Plymouth Fish Nutrition Unit and to all the staff there, to technician Andy Fisher for aid in the use of metal analysis machinery at the University of Plymouth and to volunteers and staff at the Bimini Biological Field Station for help during field data collections.

\section{LITERATURE CITED}

Anderson WG, Dasiewicz PJ, Liban S, Ryan C, Taylor JR, Grosell M, Weihrauch D (2010) Gastro-intestinal handling of water and solutes in three species of elasmobranch fish, the white-spotted bamboo shark, Chiloscyllium plagiosum, little skate, Leucoraja erinacea and the clear nose skate Raja eglanteria. Comp Biochem Physiol A 155: 493-502

AOAC (Association of Official Analytical Chemists) (1995) Official methods of analysis 16. AOAC, Washington, DC

Baker RTM, Handy RD, Davies SJ, Snook JC (1998) Chronic dietary exposure to copper affects growth, tissue lipid peroxidation, and metal composition of the grey mullet, Chelon labrosus. Mar Environ Res 45:357-365

- Bijvelds MJC, Van Der Velden JA, Kolar ZI, Flik G (1998) Magnesium transport in freshwater teleosts. J Exp Biol 201:1981-1990

Bury NR, Walker PA, Glover CN (2003) Nutritive metal uptake in teleost fish. J Exp Biol 206:11-23

Carriquiriborde P, Handy RD, Davies SJ (2004) Physiological modulation of iron metabolism in rainbow trout (Oncorhynchus mykiss) fed low and high iron diets. J Exp Biol 207:75-86

- Chapman DD, Babcock EA, Gruber SH, Dibattista JD and others (2009) Long-term natal site-fidelity by immature lemon sharks (Negaprion brevirostris) at a subtropical island. Mol Ecol 18:3500-3507

Craig JM, Thomas MV, Nichols SJ (2005) Length-weight relationship and a relative condition factor equation for lake sturgeon (Acipenser fulvescens) from the St Clair River system (Michigan, USA). J Appl Ichthyology 21:81-85

> De Boeck G, Eyckmans M, Lardon I, Bobbaers R, Sinha AK, Blust R (2010) Metal accumulation and metallothionein induction in the spotted dogfish Scyliorhinus canicula. Comp Biochem Physiol A 155:503-508

DiBattista JD, Feldheim KA, Gruber SH, Hendry AP (2007) When bigger is not better: selection against large size, high condition and fast growth in juvenile lemon sharks. J Evol Biol 20:201-212

Eddy FB (2009) Regulation of sodium in the body fluids of teleost fish in response to challenges to the osmoregulatory system. In: Handy RD, Bury N, Flik G (eds) Osmoregulation and ion transport: integrating physiological, mole- 
cular and environmental aspects. Essential Rev Exp Biol, Vol 1. Society for Experimental Biology Press, London, p 1-18

Eddy FB, Bath RN (1979) Ionic regulation in rainbow trout (Salmo gairdneri) adapted to fresh water and dilute seawater. J Exp Biol 83:181-192

Eder EB, Lewis MN (2005) Proximate composition and energetic value of demersal and pelagic prey species from the SW Atlantic Ocean. Mar Ecol Prog Ser 291:43-52

Flik G, Verbost PM, Wendelaar Bonga SE (1995) Calcium transport processes in fish. In: Wood CM, Shuttleworth TJ (eds) Cellular and molecular approaches to fish ionic regulation. Fish Physiology, Vol 14. Academic Press, London, p 317-342

Flik G, Bevelander GS, Klaren PHM (2009) Regulation of calcium and magnesium handling in teleost fish. In: Handy RD, Bury N, Flik G (eds) Osmoregulation and ion transport: integrating physiological, molecular and environmental aspects. Essential Rev Exp Biol, Vol 1. Society for Experimental Biology Press, London, p 151-180

Fraser TWK, Davies SJ (2009) Nutritional requirements of cobia, Rachycentron canadum (Linnaeus): a review. Aquacult Res 40:1219-1234

Gökoðlu N, Yerlikaya P (2003) Determination of proximate composition and mineral contents of blue crab (Callinectes sapidus) and swim crab (Portunus pelagicus) caught off the Gulf of Antalya. Food Chem 80:495-498

Halver JE (1989) Fish nutrition, 2nd edn. Academic Press, New York

> Handy RD, Sims DW, Giles A, Campbell HA, Musonda MM (1999) Metabolic trade-off between locomotion and detoxification for maintenance of blood chemistry and growth parameters by rainbow trout (Oncorhynchus mykiss) during chronic dietary exposure to copper. Aquat Toxicol 47:23-41

Handy RD, McGeer JC, Allen HE, Drevnick PE and others (2005) Toxic effects of dietborne metals: laboratory studies. In: Meyer JS, Adams WJ, Brix KV, Luoma SN and others (eds) Toxicity of dietborne metals to aquatic organisms. SETAC Press, Pensacola, FL, p 59-112

Holmes WN, Donaldson EM (1969) Body compartments and distribution of electrolytes. In: Hoar WS, Randall DJ (eds) Fish physiology, Vol 1. Academic Press, New York, NY, p 15-92

- Hossain MA, Furuichi M (2000) Essentiality of dietary calcium supplement in fingerling scorpion fish (Sebastiscus marmoratus). Aquaculture 189:155-163

> Irwin S, Davenport J (2002) Iron status of adult dogfish (Scyliorhinus canicula) tissues and sources of iron during embryonic development. J Mar Biol Assoc UK 82: 881-885

Jennings D, Gruber SH, Franks B, Kessel S, Robertson A (2008) Effects of large-scale anthropogenic development on juvenile lemon shark (Negaprion brevirostris) populations of Bimini, Bahamas. Environ Biol Fishes 83:369-377

Lawson JW, Magalhães AM, Miller EH (1998) Important prey species of marine vertebrate predators in the northwest Atlantic: proximate composition and energy density. Mar Ecol Prog Ser 164:13-20

Maage A, Lygren B, El-Mowafic AFA (2000) Manganese requirement of Atlantic salmon (Salmo salar) fry. Fish Sci $66: 1-8$

> MacKenzie S, Cutler CR, Hazon N, Cramb G (2002) The effects of dietary sodium loading on the activity and expression of $\mathrm{Na}$, K-ATPase in the rectal gland of the European dogfish (Scyliorhinus canicula). Comp Biochem Physiol B 131:185-200
McMeans BC, Borga K, Bechtol WR, Higginbotham D, Fisk AT (2007) Essential and non-essential element concentrations in two sleeper shark species collected in arctic waters. Environ Pollut 148:281-290

Morrissey JF, Gruber SH (1993) Habitat selection by juvenile lemon sharks, Negaprion brevirostris. Environ Biol Fishes 38:311-319

Naczk M, Williams J, Brennan K, Liyanapathirana C, Shahidi F (2004) Compositional characteristics of green crab (Carcinus maenus). Food Chem 88:429-434

Neufeld DS, Cameron JN (1992) Postmolt uptake of calcium by the blue-crab (Callinectes sapidus) in water of low salinity. J Exp Biol 171:283-299

Newman SP, Handy RD, Gruber SH (2007) Spatial and temporal variations in mangrove and seagrass faunal communities at Bimini, Bahamas. Bull Mar Sci 80:529-553

Newman SP, Handy DR, Gruber SH (2010) Diet and prey preference of juvenile lemon sharks, Negaprion brevirostris. Mar Ecol Prog Ser 398:221-234

NRC (National Research Council) (1993) Nutrient requirements of fish. National Academy Press, Washington, DC

Payne SA, Johnson AB, Otto RS (1999) Proximate composition of some north-eastern Pacific forage fish species. Fish Oceanogr 8:159-177

Priede IG (1977) Natural selection for energetic efficiency and the relationship between activity level and mortality. Nature 267:610-611

Priede IG (1985) Metabolic scope in fishes. In: Tytler P, Calow P (eds) Fish energetics: new perspectives. Croom Helm, London, p 33-64

Randall JE (1967) Food habits of reef fishes of the West Indies. Stud Trop Oceanogr 5:665-847

Reeve A, Handy RD, Gruber SH (2009) Prey selection and functional response of juvenile lemon sharks Negaprion brevirostris. J Fish Biol 75:276-281

Salman NA (2009) Effects of dietary salt on feeding, digestion, growth and osmoregulation in teleost fish. In: Handy RD, Bury N, Flik G (eds) Osmoregulation and ion transport: integrating physiological, molecular and environmental aspects. Essential Rev Exp Biol, Vol 1. Society for Experimental Biology Press, London, p 109-150

Scott-Fordsmand JJ, Depledge MH (1997) Changes in the tissue concentrations and contents of calcium, copper and zinc in the shore crab Carcinus maenas (L) (Crustacea: Decapoda) during the moult cycle and following copper exposure during ecdysis. Mar Environ Res 44:397-414

> Speers-Roesch B, Treberg JR (2010) The unusual energy metabolism of elasmobranch fishes. Comp Biochem Physiol A 155:417-434

Sundström LF (2005) Negaprion brevirostris. IUCN (International Union for Conservation of Nature) Red List of Threatened Species 2009.2. Downloaded 18 Feb 2010. www.iucnredlist.org

> Sundström LF, Gruber SH (1998) Using speed-sensing transmitters to construct a bioenergetics model for subadult lemon sharks, Negaprion brevirostris (Poey), in the field. Hydrobiologia 371/372:241-247

Trivett MK, Walker TI, Clement JG, Ho PMW, Martin TJ, Danks JA (2001) Effects of water temperature and salinity on parathyroid hormone-related protein in the circulation and tissues of elasmobranchs. Comp Biochem Physiol B 129:327-336

Van Anholt RD, Spanings FAT, Koven WM, Nixon O, Wendelaar Bonga SE (2004) Arachidonic acid reduces the stress response of gilthead seabream Sparus aurata L. J Exp Biol 207:3419-3430

Watanabe T, Kiron V, Satoh S (1997) Trace minerals in fish 
nutrition. Aquaculture 151:185-207

Wetherbee BM, Gruber SH (1993) Absorption efficiency of the lemon shark Negaprion Brevirostris at varying rates of energy intake. Copeia 2:416-425

Wetherbee BB, Gruber SH, Cortés E (1990) Diet, feeding habits, digestion, and consumption in sharks, with special reference to the lemon shark, Negaprion brevirostris. In: Pratt HL Jr, Gruber SH, Taniuchi T (eds) Elasmobranchs as living resources, advances in the biology, ecology, systematic and the states of the fisheries. NOAA Tech Rep,

Editorial responsibility: Inna Sokolova,

Charlotte, North Carolina, USA
NMFS 90, p 29-47

Whittamore JM, Cooper CA, Wilson RW (2010) $\mathrm{HCO}_{3}{ }^{-}$secretion and $\mathrm{CaCO}_{3}$ precipitation play major roles in intestinal water absorption in marine teleost fish in vivo. Am J Physiol 298:R877-R886

Ye CX, Tian LX, Yang HJ, Liang JJ, Niu J, Liu YJ (2009) Growth performance and tissue mineral content of juvenile grouper (Epinephelus coioides) fed diets supplemented with various levels of manganese. Aquacult Nutr 15:608-614

Submitted: July 8, 2010; Accepted: March 2, 2011

Proofs received from author(s): May 25, 2011 